ISSN: 2302-8556

E-Jurnal Akuntansi Universitas Udayana

Vol.24.2.Agustus (2018): 1413-1440

DOI: https://doi.org/10.24843/EJA.2018.v24.i02.p22

\title{
Perbedaan Abnormal Return Sebelum dan Sesudah Pemilihan Umum Gubernur DKI Jakarta Tahun 2017
}

\author{
Luh Gede Hari Purnama Sari ${ }^{1}$ \\ Gayatri $^{2}$ \\ ${ }^{1}$ Fakultas Ekonomi dan Bisnis Universitas Udayana (Unud), Bali, Indonesia \\ email: premarasa.veget@gmail.com/+6287862762462 \\ ${ }^{2}$ Fakultas Ekonomi dan Bisnis Universitas Udayana (Unud), Bali, Indonesia
}

\begin{abstract}
ABSTRAK
Peristiwa Pemilihan Umum Gubernur DKI Jakarta Tahun 2017 merupakan peristiwa politik yang mempengaruhi pasar modal. Penelitian bertujuan untuk mengetahui adanya abnormal return disekitar peristiwa Pemilihan Umum Gubernur DKI Jakarta Tahun 2017 dan untuk mengetahui perbedaan abnormal return sebelum dan sesudah peristiwa Pemilihan Umum Gubernur DKI Jakarta Tahun 2017. Penelitian dilakukan pada perusahaan yang termasuk dalam Indeks Kompas 100, periode Februari hingga Juli Tahun 2017. Sampel penelitian sejumlah 92 perusahaan ditentukan dengan metode nonprobability sampling, khususnya teknik purposive sampling. Teknik analisis penelitian adalah Chi-Square Test dan Wilcoxon Signed Ranks Test. Hasil penelitian menunjukkan terdapat abnormal return disekitar peristiwa Pemilihan Umum Gubernur DKI Jakarta Tahun 2017. Terdapat perbedaan abnormal return sebelum dan sesudah Pemilihan Umum Gubernur DKI Jakarta Tahun 2017. Peristiwa tersebut mengandung informasi dan membuat investor bereaksi. Penelitian ini membuktikan teori pasar efisien bentuk setengah kuat sebagai representasi dari respon pasar terhadap suatu peristiwa.
\end{abstract}

Kata Kunci : Abnormal return, reaksi pasar

\begin{abstract}
The General Election of DKI Jakarta Governor Year 2017 is political events affecting the capital market. This study aims to determine abnormal return around the events and to determine the difference of abnormal return before and after the events. This study was conducted in companies incorporated the Compass Index 100 period February to July Year 2017. The samples are 92 companies, determined by nonprobability sampling method, especially purposive sampling technique. Research analysis technique is Chi-Square Test and Wilcoxon Signed Ranks Test. The result are there is abnormal return around the events of General Election of DKI Jakarta Governor Year 2017. There are differences of abnormal return before and after General Election of DKI Jakarta Governor Year 2017. The events contains information and make investors react. This research can prove efficient market theory of half strong form as representation of the market response to an event.
\end{abstract}

Keywords: Abnormal return, market reaction 


\section{PENDAHULUAN}

Investasi merupakan penanaman uang atau modal dalam suatu perusahaan atau proyek untuk tujuan memperoleh keuntungan. Salah satu sarana untuk investor berinvestasi yaitu melalui pasar modal. Hartono (2015:33) menyatakan bahwa pasar modal merupakan tempat bertemu antara pembeli dan penjual dengan risiko untung rugi. Investor akan mendapatkan return sebagai hasil dari investasi. Return dapat berupa return realisasian dan return ekspektasian. Return realisasian merupakan return yang sudah terjadi dan dihitung dengan menggunakan data historis. Sedangkan return ekspektasian merupakan return yang diharapkan akan diperoleh oleh investor di masa mendatang.

Chandra et al. (2014) menyatakan bahwa terdapat dua faktor yang dapat mempengaruhi pasar modal yaitu faktor ekonomi dan faktor non ekonomi. Salah satu faktor non ekonomi yang mempengaruhi pasar modal adalah peristiwa politik. Peristiwa politik patut dipertimbangakan karena perubahan dalam suatu tindakan maupun kebijakan politik di suatu negara dapat menimbulkan dampak besar pada sektor keuangan dan perekonomian negara tersebut. Apabila situasi politik tidak menentu, maka akan menimbulkan unsur ketidakpastian dalam bisnis. Suatu peristiwa politik yang besar dapat mempengaruhi pasar modal karena berkaitan erat dengan kestabilan perekonomian suatu negara. Suryanto (2015) menyatakan peristiwa politik dapat menjadi salah satu sumber informasi yang diserap oleh para pelaku pasar dan dijadikan pedoman dalam pengambilan keputusan investasi. Laksmi dan Ratnadi (2015) membuktikan bahwa suatu 
peristiwa mengandung informasi maka pasar akan bereaksi ditandai dengan adanya perubahan harga saham.

Pemilihan Umum Gubernur DKI Jakarta (Daerah Khusus Ibukota Jakarta) Tahun 2017 merupakan salah satu peristiwa politik yang besar mengingat DKI Jakarta merupakan ibukota dan menjadi pusat ekonomi Indonesia. Dalam perjalanan Pemilihan Umum Gubernur DKI Jakarta Tahun 2017, salah satu kandidat Gubernur DKI Jakarta yakni Basuki Tjahaja Purnama tersandung kasus hukum atas dugaan penistaan agama. Kasus ini menjadi awal memanasnya situasi politik Pemilihan Umum Gubernur DKI Jakarta Tahun 2017. Situasi politik yang memanas di ibukota diwarnai dengan aksi massa besar-besaran pada tanggal 4 November 2016 atau dikenal dengan aksi 411 dan 2 Desember 2016 yang dikenal dengan aksi 212. Aksi massa pada 4 November 2017 yang menuntut agar Ahok diproses hukum secara tuntas, tidak berjalan secara kondusif. Terjadi kericuhan antara massa demonstran dengan aparat keamanan pada malam harinya, hingga membuat Presiden Jokowi menggelar rapat terbatas secara mendadak di Istana Merdeka. Presiden Jokowi juga menyatakan bahwa kekacauan yang terjadi di Jakarta sepanjang 4 November 2016 sampai dengan 5 November 2016 tersebut telah ditunggangi oleh aktor-aktor politik yang ingin memanfaatkan situasi. Puncak dari aksi massa besar - besaran terjadi pada tanggal 2 Desember 2016 dengan jumlah massa yang mengikuti aksi sebanyak satu juta orang. Massa tersebut tidak hanya berasal dari DKI Jakarta namun juga datang dari daerah lain. Aksi serupa tidak hanya berlangsung di Jakarta, sejumlah daerah juga menggelar aksi serupa secara bersamaan. Namun pada aksi 212 tidak terjadi kericuhan 
seperti pada aksi 411 karena aksi ini berupa aksi damai menggelar doa bersama (www.cnnindonesia.com).

Terwujudnya aksi damai 212 yang tidak menimbulkan kericuhan dan berjalan secara tertib, menjadi tanda bahwa siatusi politik yang memanas mulai reda. Hal ini menjadi sinyal positif bagi iklim pasar modal di Indonesia. Respon positif masyarakat Indonesia termasuk juga para investor pada saat Pemilihan Umum Gubernur DKI Jakarta Tahun 2017 dapat dilihat dari pergerakan ekonomi yang positif seperti Indeks Harga Saham Gabungan (IHSG) yang menguat 69,17 poin ke level 5664,48 pada H+1 setelah Pemilihan Umum Gubernur DKI Jakarta Tahun 2017 (www.market.bisnis.com). Menguatnya IHSG memberikan dampak positif terhadap investor karena fungsi dari IHSG tersebut sebagai penanda arah pasar, pengukur tingkat keuntungan (return) dan tolak ukur kinerja portofolio (Yuniarthi, 2016). Para investor yang menanamkan modal di pasar modal tentunya mengharapkan return sebagai imbalan. Melihat respon positif yang diberikan oleh pasar yang ditandai dengan naiknya IHSG memberikan ketertarikan untuk menguji return yang diterima akibat pengaruh dari peristiwa tersebut. Apabila return yang diterima lebih besar dibandingkan dengan return realisasian maka akan terdapat abnormal return positif, sedangkan apabila return yang diterima lebih kecil dibandingkan return realisasi maka akan terdapat abnormal return negatif. Abnormal return merupakan selisih antara return realisasi dengan return ekspektasi.

Wardhani dan Djazuli (2012) melakukan event study mengenai reaksi pasar modal Indonesia terhadap salah satu peristiwa politik dalam negeri yaitu 
Peristiwa Pemilihan Gubernur DKI Jakarta Putaran II 2012 dengan hasil yang diperoleh bahwa terdapat abnormal return pada beberapa hari di sekitar tanggal peristiwa. Respati (2014) melakukan penelitian mengenai reaksi pasar modal terhadap pengumuman sengketa hasil pemilihan presiden 2014 dengan hasil penelitian menunjukkan bahwa terdapat abnormal return disekitar tanggal peristiwa. Savita dan Ramesh (2015) meneliti tentang abnormal return disekitar pemilihan nasional di India. Hasilnya adalah investor mendapatkan abnormal return selama pemilihan nasional. Penelitian yang dilakukan oleh Imelda dan Anggraeni (2014) mendapatkan hasil bahwa terdapat perbedaan signifikan antara Average Abnormal Return dan Average Trading Volume Activity sebelum dan sesudah peristiwa pemilihan umum Presiden dan Wakil Presiden tahun 2009.

Penelitian untuk mengetahui terjadinya abnormal return telah banyak dilakukan pada berbagai peristiwa politik yang telah terjadi. Namun pada penelitian ini, peneliti memilih peristiwa politik Pemilihan Umum Gubernur DKI Jakarta Tahun 2017 yang dilaksanakan pada Bulan April tahun 2017. Penelitian ini bertujuan untuk memberikan gambaran bahwa Pemilihan Umum Gubernur DKI Jakarta Tahun 2017 dapat memengaruhi harga saham anggota Indeks Kompas 100.

Berdasarkan latar belakang di atas maka peneliti tertarik untuk meneliti adanya abnormal return disekitar tanggal peristiwa Pemilihan Umum Gubernur DKI Jakarta Tahun 2017 dan perbedaan abnormal return sebelum dan sesudah peristiwa Pemilihan Umum Gubernur DKI Jakarta Tahun 2017 dengan judul 
"Perbedaan Abnormal Return Sebelum dan Sesudah Pemilihan Umum Gubernur DKI Jakarta Tahun 2017”

Berdasarkan latar belakang tersebut, maka yang menjadi pokok permasalahan dalam penelitian ini adalah apakah terdapat abnormal return disekitar Pemilihan Umum Gubernur DKI Jakarta Tahun 2017, dan apakah terdapat perbedaan abnormal return sebelum dan sesudah Pemilihan Umum Gubernur DKI Jakarta Tahun 2017. Tujuan penelitian adalah untuk menguji secara empiris abnormal return di sekitar Pemilihan Umum Gubernur DKI Jakarta Tahun 2017 dan untuk menguji perbedaan abnormal return sebelum dan sesudah Pemilihan Umum Gubernur DKI Jakarta Tahun 2017.

Kegunaan teoritis penelitian yaitu dapat memberikan konfirmasi atas teori pasar efisien disekitar Pemilihan Umum Gubernur DKI Jakarta Tahun 2017. Kegunaan praktis penelitian ini dapat menjadi masukan bagi para investor dan pihak yang berkepentingan agar dapat mempertimbangkan keputusan yang akan diambil pada saat peristiwa politik terjadi.

Teori pasar efisien merupakan keadaan pasar di mana harga semua sekuritas yang diperdagangkan telah mencerminkan informasi yang tersedia. Purnama dan Khairunnisa (2015) menyatakan pasar yang efisien adalah pasar dimana harga semua sekuritas yang diperdagangkan telah mencerminkan semua informasi yang tersedia. Pasar efisien dapat diklasifikasikan ke dalam tiga bentuk Efficient Market Hypothesis (EMH) (Fama, 1969 ; Tandelilin, 2010:230) yaitu pasar efisien bentuk lemah, bentuk setengah kuat, bentuk kuat. 
Investasi adalah penanaman modal untuk satu atau lebih aktiva yang dimiliki dan biasanya berjangka waktu lama dengan harapan mendapatkan keuntungan di masa-masa yang akan datang (Hartono, 2015:234). Sedangkan menurut Ikatan Akuntan Indonesia atau IAI (2011) dalam PSAK investasi merupakan suatu aktiva yang dikelola oleh perusahaan yang meningkatkan nilai investasi dan manfaat lebih lainnya bagi perusahaan. Menurut Fahmi dan Irham (2012:3) investasi adalah salah pengelolaan dana untuk memberikan keuntungan bagi investor dengan menempatkan dana pada alokasi yang diperkirakan dapat memberikan keuntungan. Investasi aset finansial dapat dilakukan pada pasar modal (Mentari, 2016).

Pasar modal merupakan salah satu sarana dalam melakukan investasi. Menurut Hartono (2015:9) pasar modal merupakan tempat bertemu antara pembeli dan penjual dengan risiko untung rugi. Pasar modal digunakan sebagai sarana pendanaan usaha atau sebagai sarana bagi perusahaan untuk mendapatkan dana dari masyarakat pemodal. Selain itu pasar modal juga menjadi sarana bagi masyarakat untuk berinvestasi pada instrumen keuangan. Menurut Nabila dan Khairunnisa (2015) ; Puteri (2017) pasar modal berfungsi sebagai sarana alokasi dana untuk memindahkan dari pemberi pinjaman ke penerima pinjaman. Pasar modal berperanan penting bagi perekonomian karena dapat menghubungkan pihak yang memiliki kelebihan dana dengan pihak yang kekurangan dana.

Studi peristiwa (event study) merupakan studi yang menyelidiki respon pasar terhadap kandungan informasi dari suatu pengumuman atau publikasi peristiwa. Peristiwa tersebut dapat berupa peristiwa ekonomi maupun peristiwa 
non ekonomi yang tujuannya untuk mengetahui ada atau tidaknya abnormal return yang diperoleh pemegang saham (Wibowo, 2017). Studi peristiwa merupakan bentuk studi yang digunakan untuk menguji efisiensi pasar bentuk setengah kuat (semi strong form) (Tandelilin, 2010:565). Secara empiris bentuk pengujian yang umum digunakan dalam studi peristiwa adalah bertujuan untuk menguji adanya abnormal return di seputar pengumuman peristiwa (Tandelilin, 2010:571). Peterson (1989) menjelaskan bahwa event study merupakan pengamatan mengenai pergerakan saham untuk mengetahui adanya abnormal return akibat adanya suatu peristiwa. Jika peristiwa yang dipublikasikan mengandung informasi yang relevan maka diharapkan pasar akan bereaksi yang di tunjukkan dengan adanya perubahan harga saham (Putri, 2016). Julio dan Yook (2012) menyatakan bahwa ketidakpastian politik menyebabkan menurunnya perusahaan yang berinvestasi yang dapat mempengaruhi pasar modal. Reaksi pasar tercermin dari adanya return yang diperoleh. Apabila terdapat selisih antara return realisasian dengan return ekspektasian maka terdapat abnormal return.

Investor melakukan investasi dengan harapan akan memperoleh keuntungan di kemudian hari yang berupa return. Return dapat berupa return realisasian (realized return) dan return ekspektasian (expected return). Menurut Hartawan (2015) setiap return yang diterima sebagai imbalan dari saham yang ditanamkan adalah return realisasi, sedangkan return yang diharapkan diterima dimasa depan adalah return ekspektasi. Selisih antara return realisasian dengan return ekspektasian adalah abnormal return (Hartono, 2015:648; Cahyono, 2017). Reaksi investor terhadap suatu peristiwa politik dapat dilihat dengan 
menggunakan abnormal return. Apabila suatu peristiwa tidak menyebabkan terjadinya abnormal return berarti tidak terdapat reaksi dari investor atau tidak terdapat reaksi pasar (Utami, 2017; Zulfikar, 2017). Reaksi pasar terhadap adanya peristiwa politik dapat dilihat dari adanya abnormal return (Hartono, 2015:555). Pratama (2015) menyatakan abnormal return merupakan indikator yang digunakan untuk mengukur reaksi pasar akibat terjadinya suatu peristiwa tertentu.

Pemilihan Umum Gubernur DKI Jakarta Tahun 2017 merupakan pesta demokrasi dalam memilih Gubernur dan Wakil Gubernur DKI Jakarta untuk Periode 2017-2022. Pilgub DKI Jakarta dilaksanakan dua putaran yaitu pada 15 Februari 2017 dan 19 April 2017. Pilgub DKI Jakarta Tahun 2017 merupakan pemilihan kepala daerah ketiga bagi Jakarta yang dilakukan secara langsung dengan menggunakan sistem pencoblosan. Pilkada DKI Jakarta yang pada kali ini memberikan dampak secara tidak langsung bagi pasar modal. Hal ini tercermin dari IHSG yang menguat 69,17 poin ke level 5664,48 pada $H+1$ setelah Pemilihan Umum Gubernur DKI Jakarta Tahun 2017 (www.market.bisnis.com).

Teori Pasar efisien merupakan keadaan pasar di mana harga semua sekuritas yang diperdagangkan telah mencerminkan informasi yang tersedia. Abnormal return terjadi pada keadaan pasar efisien bentuk setengah kuat, dan hanya terjadi di seputar pengumuman (publikasi) suatu peristiwa sebagai representasi dari respon pasar terhadap pengumuman atau peristiwa. Pemilihan Umun Gubernur DKI Jakarta Tahun 2017 merupakan sebuah peristiwa politik yang berdampak secara tidak langsung ke dunia pasar modal karena keadaan politik akan mempengaruhi perekonomian suatu negara. Pasar modal akan 
bereaksi apabila terdapat suatu kandungan informasi yang diterima oleh investor pada saat peristiwa terjadi. Apabila suatu peristiwa mengandung informasi maka akan terdapat abnormal return disekitar tanggal peristiwa Pemilihan Umum Gubernur DKI Jakarta Tahun 2017. Menurut Hartono (2015:558) apabila pengumuman atau suatu peristiwa memiliki kandungan informasi maka investor akan memeroleh abnormal return.

Event study yang dilakukan oleh Respati (2014) menyatakan bahwa terdapat abnormal return disekitar tanggal pengumuman sengketa hasil pemilihan presiden tahun 2014. Hal ini menunjukkan bahwa peristiwa tersebut memiliki kandungan informasi. Wardhani dan Djazuli (2012) yang menyatakan terdapat abnormal return di sekitar tanggal peristiwa Pemilihan Gubernur DKI Jakarta Putaran II 2012. Penelitiasn menurut Purba (2017) menyatakan terdapat abnormal return yang bernilai negatif signifikan di sekitar periode peristiwa politik Pilkada DKI Jakarta 2017 Putaran Kedua. Berdasarkan penjelasan diatas, penulis membangun hipotesis dalam penelitian ini adalah:

$\mathrm{H}_{1}$ : Terdapat abnormal return disekitar peristiwa Pemilihan Umum Gubernur DKI Jakarta Tahun 2017.

Indeks Harga Saham Gabungan (IHSG) yang merupakan penanda arah pasar, pengukur tingkat keuntungan (return) dan tolak ukur kinerja portofolio menguat pada awal perdagangan tanggal 20 April 2017 pasca Pemilihan Umum Gubernur DKI Jakarta Tahun 2017. IHSG pada tanggal 20 April 2017 dibuka dengan kenaikan tipis 3,37 poin di level $5.609,89$ dan menguat 8,88 poin ke level 5.615,39 pada pukul 09.13 WIB. IHSG pada tanggal 20 April 2017 ditutup pada level 5595,31. Pada tanggal 21 April 2017 IHSG naik 69,17 poin ke level 5664,48 
(www.market.bisnis.com). Dengan penguatan IHSG diduga pasar modal bereaksi dengan adanya peristiwa Pemilihan Umum Gubernur DKI Jakarta Tahun 2017. Reaksi pasar modal dapat dilihat dengan terdapat perbedaan abnormal return sebelum dan sesudah Pemilihan Umum Gubernur DKI Jakarta Tahun 2017.

Penelitian yang dilakukan oleh Permana (2013) menunjukkan terdapat perbedaan abnormal return positif signifikan setelah peristiwa Pilkada Gubernur DKI Jakarta 20 September 2012. Nezerwe (2013) menyatakan terdapat dampak positif dari tingkat return yang diperoleh ketika terjadi pemilihan presiden. Demikian juga dengan penelitian yang dilakukan oleh Sirait (2012) menyatakan bahwa terdapat perbedaan antara average abnormal return yang signifikan pada saat peristiwa pergantian menteri keuangan dengan hari-hari sebelum peristiwa pergantian menteri keuangan. Berdasarkan penjelasan diatas, penulis membangun hipotesis dalam penelitian ini adalah:

$\mathrm{H}_{2}$ : Terdapat perbedaan abnormal return sebelum dan sesudah peristiwa Pemilihan Umum Gubernur DKI Jakarta Tahun 2017.

\section{METODE PENELITIAN}

Penelitian ini menggunakan penelitian komparatif dengan pendekatan Market Adjust Model. Penelitian ini menggunakan studi peristiwa yang mempelajari reaksi pasar terhadap suatu peristiwa. Periode peristiwa enelitian adalah selama 11 hari dalam rentang waktu Pemilihan Umum Gubernur DKI Jakarta 2017. Penelitian dilakukan pada perusahaan yang termasuk dalam Indeks Kompas 100. Obyek penelitian yaitu abnormal return pada saham-saham perusahaan yang termasuk kedalam Indeks Kompas 100. Variabel yang digunakan yaitu variabel 
terikat adalah abnormal return dan variabel bebas adalah peristiwa Pemilihan Umum Gubernur DKI Jakarta Tahun 2017.

Actual return dalam penelitian ini dihitung dengan formula sebagai berikut (Hartono, 2015:265):

$$
R_{i t}=\frac{P_{i t}-P_{i, t-1}}{P_{i, t-1}}
$$

Keterangan:

$R_{i t}=$ Return sesungguhnya sekuritas ke-i pada periode peristiwa ke-t

$P_{i t} \quad=$ Harga sekarang relatif

Pi,t-1 = Harga sebelumnya

Selanjutnya menghitung return pasar harian dengan menggunakan Indeks Kompas 100, dihitung dengan rumus sebagai berikut (Hartono, 2015:648):

$$
R_{M t}=\frac{\mathrm{IHSG}_{\mathrm{t}}-\mathrm{IHSG}_{\mathrm{t}-1}}{\mathrm{IHSG}_{\mathrm{t}-1}}
$$

\section{IHSG $_{\mathrm{t}-1}$}

Keterangan:

$R_{M t} \quad=$ Return pasar pada periode ke- $\mathrm{t}$

IHSGt $=$ Indeks Harga Saham Gabungan hari ke-t

IHSGt = Indeks Harga Saham Gabungan hari ke - t-1

Kemudian menghitung besarnya abnormal return dengan menggunakan Market Adjust Model untuk masing-masing perusahaan. Market adjust model menganggap bahwa return sekuritas yang diestimasi adalah sama dengan return indeks pasar pada saat tersebut sehingga tidak diperlukan untuk membentuk model estimasi, dapat dihitung sebagai berikut (Hartono, 2015:659):

$$
R T N_{i, t}=R_{i, t}-R_{m, t}
$$

Keterangan:

$R T N i, t=$ Abnormal return sekuritas ke-i periode estimasi ke-t

$R i, t=$ Return realisasian sekuritas ke-i pada periode estimasi ke-t

$R m, t=$ Return indeks pasar pada periode estimasi ke-t 
Menentukan rata-rata abnormal return dapat dihitung sebagai berikut sebagai berikut (Hartono, 2015:660):

$$
R R T N_{t}=\frac{\sum_{i=1}^{k} R T N i, t}{K}
$$

Keterangan:

$R_{R T N}=$ Rata-rata abnormal return k-sekuritas untuk hari ke-t di periode peristiwa

$R T N i, t=$ Abnormal return sekuritas ke-i untuk hari ke-t di periode peristiwa

$k \quad=$ jumlah sekuritas

Populasi penelitian yaitu perusahaan-perusahaan yang termasuk kedalam Indeks Kompas 100 pada saat periode penelitian, yaitu sebanyak 100 perusahaan pada tahun 2017 periode Februari sampai dengan Juli Tahun 2017 (www.idx.co.id) . Metode yang digunakan dalam menentukan sampel yang dipilih adalah nonprobability sampling dengan pendekatan purposive sampling. Kriteria saham yang akan dijadikan sampel adalah perusahaan yang konsisten dalam Indeks Kompas 100 selama periode penelitian, sampel penelitian sebanyak 92 perusahaan.

Metode pengumpulan data dalam penelitian ini adalah metode observasi non partisipan melalui pengamatan dan mencatat dengan mengakses situs web BEI. Data yang diperoleh berupa harga saham, laporan harga penutupan saham laporan historis lainnya. Jenis data dalam penelitian adalah data kuantitatif berupa daftar harga saham dari laporan harga penutupan saham perusahaan-perusahaan yang termasuk dalam Indeks Kompas 100 dan harga IHSG pada peristiwa yang diamati. Sumber data penelitian adalah data sekunder berupa data closing price Indeks Kompas 100 yang dipublikasikan oleh BEI. 
Sebelum melakukan pengujian Hipotesis, dilakukan uji normalitas untuk mengetahui apakah data berdistribusi normal atau tidak. Metode yang digunakan yaitu dengan statistik Kolmogorov-Smirnov. Data dapat dikatakan berdistribusi normal apabila Asymp.sig (2-tailed) $>\alpha$ (Ghozali, 2013:165). Teknik analisis data yang digunakan dalam penelitian ini yaitu untuk Hipotesis 1 dengan menggunakan uji One Sample T-Test apabila data berdistribusi normal sedangkan apabila tidak berdistribusi normal menggunakan uji Chi-Square Test. Teknik analisis data untuk Hipotesis 2 dengan menggunakan uji Paired Sample T-Test apabila data berdistribusi normal sedangkan apabila data tidak berdistribusi normal menggunakan uji Wilcoxon Signed Ranks Test dibantu dengan menggunakan program SPSS (Statistical Product and Service Solution).

\section{HASIL DAN PEMBAHASAN}

Statistik deskriptif memberikan gambaran suatu data. Gambaran tersebut dapat dilihat dari jumlah sampel, nilai minimum, nilai maksimum, nilai rata-rata, dan standar deviasi masing-masing variabel di dalam penelitian.

Tabel 1.

Statistik Deskriptif Abnormal Return Sebelum dan Sesudah Peristiwa Pemilihan Umum Gubernur DKI Jakarta Tahun 2017

\begin{tabular}{cccccc}
\hline & N & Minimum & Maximum & Mean & Std. Deviation \\
\hline H-5 & 92 & $-1181,06$ & $-1179,93$ & $-1180,07$ & 0,11 \\
H-4 & 92 & $-1185,96$ & $-1185,59$ & $-1185,83$ & 0,04 \\
H-3 & 92 & $-1178,36$ & $-1178,21$ & $-1178,30$ & 0,02 \\
H-2 & 92 & $-1167,20$ & $-1167,11$ & $-1167,16$ & 0,01 \\
H-1 & 92 & $-1176,34$ & $-1175,22$ & $-1175,38$ & 0,21
\end{tabular}




$\begin{array}{llllll}\text { H } 0 & 92 & -1173,05 & -1172,02 & -1172,08 & 0,15 \\ \mathrm{H}+1 & 92 & -1190,83 & -1189,75 & -1189,84 & 0,11 \\ \mathrm{H}+2 & 92 & -1193,47 & -1193,37 & -1193,43 & 0,02 \\ \mathrm{H}+3 & 92 & -1205,60 & -1205,44 & -1205,55 & 0,02 \\ \mathrm{H}+4 & 92 & -1200,14 & -1199,98 & -1200,05 & 0,02 \\ \mathrm{H}+5 & 92 & -1194,45 & -1194,12 & -1194,33 & 0,03\end{array}$

Sumber: Data diolah, 2017.

Tabel 1 menunjukkan nilai minimum ke-11 periode tersebut sebesar 1205,60 pada saat H+3. Nilai minimum diperoleh perusahaan Gajah Tunggal Tbk. Nilai maksimum ke-11 periode tersebut sebesar $-1167,11$ pada saat $\mathrm{H}-2$. Nilai maksimun diperoleh perusahaan Kimia Farma Tbk. Nilai rata - rata untuk ke-11 periode tersebut sebesar $-1185,64$. Nilai rata - rata standar deviasinya sebesar 0,07 .

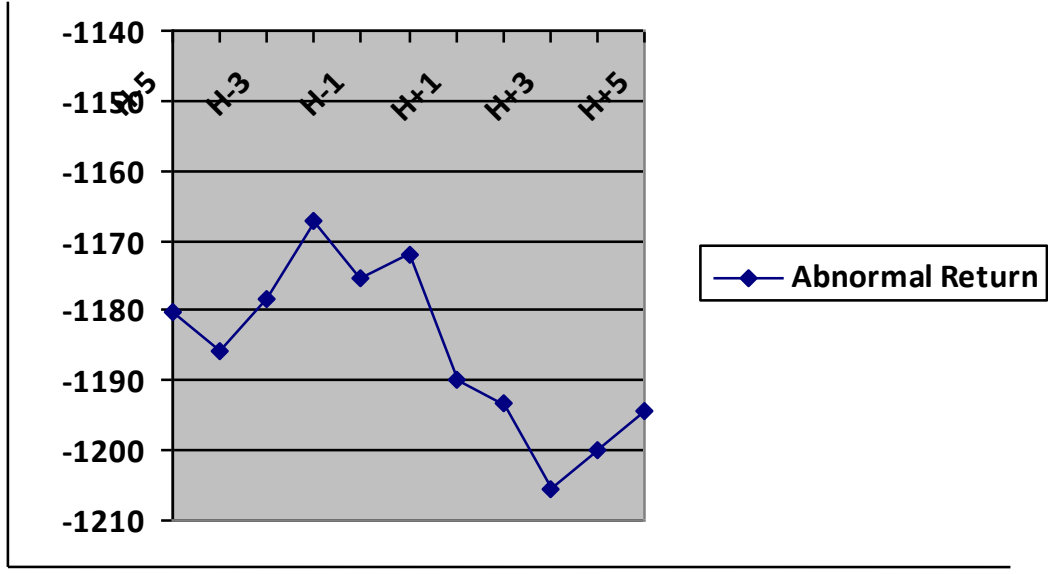

Sumber : Data diolah, 2017.

Gambar 1.

Grafik Rata-Rata Abnormal Return Sebelum dan Sesudah Pemilihan Umum Gubernur DKI Jakarta Tahun 2017

Gambar 1 menunjukkan terjadi fluktuasi abnormal return dari kondisi H-5 hingga kondisi H+ 5 Pemilihan Umum Gubernur DKI Jakarta Tahun 2017, diawali dengan -1180,07; -1185,83;-1178,30;-1167,16; -1175,38; -1172,08; - 
1189,$84 ;-1193,43 ;-1205,55 ;-1200,05$; hingga -1194,33. Terjadinya fluktuasi dari abnormal return menunjukkan bahwa situai dan kondisi $\mathrm{H}-5$ hingga kondisi $\mathrm{H}+5$ peristiwa Pemilihan Umum Gubernur DKI Jakarta Tahun 2017 memiliki kandungan informasi. Dengan adanya kandungan informasi yang cukup maka dapat membuat pasar modal bereaksi.

Dalam penelitian ini, uji normalitas dilakukan untuk mengetahui apakah data dari variabel abnormal return disekitar peristiwa Pemilihan Umum Gubernur DKI Jakarta Tahun 2017 berdistribusi normal atau tidak. Data berdistribusi normal apabila nilai signifikansi lebih besar dari nilai $\alpha(0,05)$. Hasil uji normalitas data abnormal return disekitar peristiwa Pemilihan Umum Gubernur DKI Jakarta Tahun 2017 dapat dilihat pada Tabel 2.

Tabel 2.

Uji Normalitas Data Abnormal Return Disekitar Peristiwa Pemilihan Umum Gubernur DKI Jakarta Tahun 2017

\begin{tabular}{cccc}
\hline & $\begin{array}{c}\text { Asymp. Sig } \\
\text { (2-Tailed) }\end{array}$ & Kriteria & Keterangan \\
\hline H-5 & 0,000 & 0,05 & Distribusi Tidak Normal \\
H-4 & 0,002 & 0,05 & Distribusi Tidak Normal \\
H-3 & 0,001 & 0,05 & Distribusi Tidak Normal \\
H-2 & 0,003 & 0,05 & Distribusi Tidak Normal \\
H-1 & 0,000 & 0,05 & Distribusi Tidak Normal \\
H 0 & 0,000 & 0,05 & Distribusi Tidak Normal \\
H+1 & 0,000 & 0,05 & Distribusi Tidak Normal \\
H+2 & 0,017 & 0,05 & Distribusi Tidak Normal \\
H+3 & 0,001 & 0,05 & Distribusi Tidak Normal \\
H+4 & 0,007 & 0,05 & Distribusi Tidak Normal \\
H+5 & 0,000 & 0,05 & Distribusi Tidak Normal \\
\hline
\end{tabular}

Sumber: Data diolah, 2017.

Berdasarkan Tabel 2, dapat diketahui bahwa hasil uji normalitas data dengan menggunakan uji Kolmogorov-Smirnov, variabel abnormal return H-5 peristiwa Pemilihan Umum Gubernur DKI Jakarta Tahun 2017 menunjukkan nilai 
signifikansi sebesar $0,000<$ dari nilai $\alpha$ sebesar 0,05 berarti bahwa data memiliki distribusi tidak normal. Variabel abnormal return H-4 peristiwa Pemilihan Umum Gubernur DKI Jakarta Tahun 2017 menunjukkan nilai signifikansi sebesar 0,002 $<$ dari nilai $\alpha$ sebesar 0,05 berarti bahwa data memiliki distribusi tidak normal. Variabel abnormal return H-3 peristiwa Pemilihan Umum Gubernur DKI Jakarta Tahun 2017 menunjukkan nilai signifikansi sebesar 0,001 < dari nilai $\alpha$ sebesar 0,05 berarti bahwa data memiliki distribusi tidak normal. Variabel abnormal return H-2 peristiwa Pemilihan Umum Gubernur DKI Jakarta Tahun 2017 menunjukkan nilai signifikansi sebesar $0,003<$ dari nilai $\alpha$ sebesar 0,05 berarti bahwa data memiliki distribusi tidak normal. Variabel abnormal return $\mathrm{H}-1$ peristiwa Pemilihan Umum Gubernur DKI Jakarta Tahun 2017 menunjukkan nilai signifikansi sebesar $0,000<$ dari nilai $\alpha$ sebesar 0,05 berarti bahwa data memiliki distribusi tidak normal. Variabel abnormal return $\mathrm{H}+1$ peristiwa Pemilihan Umum Gubernur DKI Jakarta Tahun 2017 menunjukkan nilai signifikansi sebesar $0,000<$ dari nilai $\alpha$ sebesar 0,05 berarti bahwa data memiliki distribusi tidak normal. Variabel abnormal return $\mathrm{H}+2$ peristiwa Pemilihan Umum Gubernur DKI Jakarta Tahun 2017 menunjukkan nilai signifikansi sebesar $0,017<$ dari nilai $\alpha$ sebesar 0,05 berarti bahwa data memiliki distribusi tidak normal. Variabel abnormal return $\mathrm{H}+3$ peristiwa Pemilihan Umum Gubernur DKI Jakarta Tahun 2017 menunjukkan nilai signifikansi sebesar $0,001<$ dari nilai $\alpha$ sebesar 0,05 berarti bahwa data memiliki distribusi tidak normal. Variabel abnormal return H+4 peristiwa Pemilihan Umum Gubernur DKI Jakarta Tahun 2017 menunjukkan nilai signifikansi sebesar $0,007<$ dari nilai $\alpha$ sebesar 0,05 berarti bahwa data 
memiliki distribusi tidak normal. Variabel abnormal return $\mathrm{H}+5$ peristiwa Pemilihan Umum Gubernur DKI Jakarta Tahun 2017 menunjukkan nilai signifikansi sebesar $0,000<$ dari nilai $\alpha$ sebesar 0,05 berarti data memiliki distribusi tidak normal. Oleh karena variabel abnormal return disekitar peristiwa Pemilihan Umum Gubernur DKI Jakarta Tahun 2017 memiliki distribusi data tidak normal, maka dapat diteruskan analisanya menggunakan uji Chi-Square Test.

Dalam penelitian ini, uji normalitas dilakukan untuk mengetahui apakah data dari variabel abnormal return sebelum dan sesudah peristiwa Pemilihan Umum Gubernur DKI Jakarta Tahun 2017 berdistribusi normal atau tidak. Data berdistribusi normal apabila nilai signifikansi > dari $\alpha$ sebesar 0,05 . Hasil uji normalitas data abnormal return sebelum dan sesudah peristiwa Pemilihan Umum Gubernur DKI Jakarta 2017 dapat dilihat dari Tabel 3.

Tabel 3.

Uji Normalitas Data Abnormal Return Sebelum dan Sesudah Peristiwa Pemilihan Umum Gubernur DKI Jakarta 2017

\begin{tabular}{cccc}
\hline Variabel & $\begin{array}{c}\text { Asymp. Sig } \\
(2-\text { Tailed })\end{array}$ & Kriteria & Keterangan \\
\hline Abnormal Return Sebelum & 0,000 & 0,05 & Distribusi Tidak Normal \\
Abnormal Return Sesudah & 0,000 & 0,05 & Distribusi Tidak Normal \\
\hline
\end{tabular}
Sumber: Data diolah, 2017.

Berdasarkan Tabel 3 dapat diketahui bahwa hasil uji normalitas data variabel abnormal return sebelum dan sesudah peristiwa Pemilihan Umum Gubernur DKI Jakarta Tahun 2017 dengan menggunakan uji KolmogorovSmirnov menunjukkan nilai signifikansi sebesar 0,000 . Oleh karena nilai signifikansi $0,000<$ dari nilai $\alpha 0,05$, hal ini berarti bahwa variabel abnormal return sebelum dan sesudah peristiwa Pemilihan Umum Gubernur DKI Jakarta 
Tahun 2017 memiliki distribusi data yang tidak normal. Oleh karena variabel abnormal return sebelum dan sesudah peristiwa Pemilihan Umum Gubernur DKI Jakarta Tahun 2017 memiliki distribusi data yang tidak normal, maka dapat diteruskan analisanya menggunakan uji Wilcoxon Signed Ranks Test.

Hipotesis 1 menyatakan terdapat abnormal return disekitar peristiwa Pemilihan Umum Gubernur DKI Jakarta Tahun 2017. Pengujian Hipotesis 1 dilakukan dengan menggunakan uji Chi-Square Test. Pengambilan keputusan dari metode ini adalah dengan melihat perbandingan nilai signifikansi dengan nilai $\alpha$. Apabila nilai signifikansi < nilai $\alpha$ maka Hipotesis 1 diterima sedangkan apabila nilai signifikansi > nilai $\alpha$ maka Hipotesis 1 ditolak.

Tabel 4.

Uji Chi-Square Test Adanya Abnormal Return Disekitar Peristiwa Pemilihan Umum Gubernur DKI Jakarta Tahun 2017

\begin{tabular}{cccc}
\hline & Asymp. Sig (2-Tailed) & Kriteria & Keterangan \\
\hline H-5 & 0,000 & 0,05 & Signifikan \\
H-4 & 0,000 & 0,05 & Signifikan \\
H-3 & 0,000 & 0,05 & Signifikan \\
H-2 & 0,000 & 0,05 & Signifikan \\
H-1 & 0,000 & 0,05 & Signifikan \\
H & 0,000 & 0,05 & Signifikan \\
H+1 & 0,000 & 0,05 & Signifikan \\
H+2 & 0,000 & 0,05 & Signifikan \\
H+3 & 0,000 & 0,05 & Signifikan \\
H+4 & 0,000 & 0,05 & Signifikan \\
H+5 & 0,000 & 0,05 & Signifikan \\
\hline
\end{tabular}

Sumber: Data diolah, 2017.

Berdasarkan Tabel 4 dapat diketahui bahwa hasil uji Hipotesis 1 dengan menggunakan uji Chi-Square Test menunjukkan variabel abnormal return $\mathrm{H}-5$, $\mathrm{H}-4, \mathrm{H}-3, \mathrm{H}-2, \mathrm{H}-1, \mathrm{H} 0, \mathrm{H}+1, \mathrm{H}+2, \mathrm{H}+3, \mathrm{H}+4, \mathrm{H}+5$ peristiwa Pemilihan Umum Gubernur DKI Jakarta Tahun 2017 memiliki nilai signifikansi sebesar 0,000 < dari nilai $\alpha$ sebesar 0,05 . Oleh karena nilai signifikansi variabel abnormal return 
$\mathrm{H}-5, \mathrm{H}-4, \mathrm{H}-3, \mathrm{H}-2, \mathrm{H}-1, \mathrm{H} 0, \mathrm{H}+1, \mathrm{H}+2, \mathrm{H}+3, \mathrm{H}+4, \mathrm{H}+5$ sebesar $0,000<$ dari nilai $\alpha$ sebesar 0,05 maka Hipotesis 1 diterima. Hal ini berarti bahwa terdapat abnormal return disekitar peristiwa Pemilihan Umum Gubernur DKI Jakarta Tahun 2017.

Hipotesis 2 menyatakan terdapat perbedaan abnormal return sebelum dan sesudah peristiwa Pemilihan Umum Gubernur DKI Jakarta Tahun 2017. Pengujian Hipotesis 2 dilakukan dengan menggunakan menggunakan uji Wilcoxon Signed Ranks Test. Pengambilan keputusan dari metode ini adalah dengan melihat perbandingan nilai signifikansi dengan nilai $\alpha$ sebesar 0,05 . Apabila nilai signifikansi $<$ nilai $\alpha$ sebesar 0,05 maka Hipotesis 2 diterima, sedangkan apabila nilai signifikansi > dari nilai $\alpha$ 0,05 maka Hipotesis 2 ditolak.

Hasil uji Hipotesis 2 dengan menggunakan uji Wilcoxon Signed Ranks Test menunjukkan bahwa variabel abnormal return sebelum dan sesudah peristiwa Pemilihan Umum Gubernur DKI Jakarta Tahun 2017 memiliki nilai signifikansi sebesar 0,000. Oleh karena nilai signifikansi $0,000<$ dari nilai $\alpha$ sebesar 0,05 maka Hipotesis 2 diterima. Hal ini berarti bahwa terdapat perbedaan abnormal return sebelum dan sesudah peristiwa Pemilihan Umum Gubernur DKI Jakarta Tahun 2017.

Hasil analisis menunjukkan bahwa terdapat abnormal return disekitar peristiwa Pemilihan Umum Gubernur DKI Jakarta Tahun 2017. Terdapat abnormal return disekitar peristiwa Pemilihan Umum Gubernur DKI Jakarta Tahun 2017 menandakan bahwa peristiwa politik tersebut mengandung informasi yang relevan bagi investor untuk pengambilan keputusan dalam melakukan 
investasi. Abnormal return terjadi disebabkan karena investor bereaksi dengan adanya informasi yang diperoleh mengenai peristiwa politik Pemilihan Umum Gubernur DKI Jakarta Tahun 2017. Informasi yang diperoleh dijadikan sebagai pertimbangan dalam pengambilan keputusan.

Selain karena adanya informasi yang diterima oleh investor, kestabilan politik pada saat Pemilihan Umum Gubernur DKI Jakarta Tahun 2017 juga menjadi pertimbangan investor dalam melakukan investasi. Kestabilan politik saat Pemilihan Umum Gubernur DKI Jakarta Tahun 2017 ditunjukkan dengan tidak terjadi kesuruhan pasca Pemilihan Umum Gubernur DKI Jakarta Tahun 2017. Kestabilan politik sangat berpengaruh terhadap pasar modal karena kondisi politik yang stabil menandakan kondisi ekonomi dan keamanan yang stabil. Dengan stabilnya kondisi politik menjadi pertimbangan investor untuk masuk ke pasar modal sehingga terdapat abnormal return disekitar peristiwa Pemilihan Umum Gubernur DKI Jakarta Tahun 2017. Hal yang sama diungkapkan oleh Purba (2017) bahwa dengan meningkatnya stabilitas politik dan keamanan menjelang dan setelah Pilkada DKI Jakarta menyebabkan investor kembali masuk ke pasar modal sehingga terjadi abnormal return.

Penelitian ini sesuai dengan teori pasar efisien bentuk setengah kuat yang menyatakan bahwa abnormal return terjadi di seputar tanggal pengumuman atau tanggal peristiwa. Hasil penelitian ini didukung oleh penelitian yang dilakukan oleh Respati (2014) menyatakan bahwa terdapat abnormal return disekitar tanggal pengumuman sengketa hasil pemilihan presiden tahun 2014. Hasil penelitian yang sama juga dilakukan oleh Wardhani dan Djazuli (2012) menyatakan bahwa 
terdapat abnormal return bernilai posotif signifikan pada Pemilihan Gubernur DKI Jakarta Putaran II. Serta penelitian yang dilakukan oleh Diniar dan Kiryanto (2015) menyatakan bahwa terdapat rata-rata abnormal return saham yang positif pada pemilu Presiden Jokowi.

Berdasarkan analisis, dapat diketahui bahwa terdapat perbedaan abnormal return sebelum dan sesudah peristiwa Pemilihan Umum Gubernur DKI Jakarta Tahun 2017. Dari hasil penelitian yang diperoleh, ditemukan terdapat perbedaan abnormal return pada saat sebelum dan sesudah Pemilihan Umum Gubernur DKI Jakarta Tahun 2017. Hal ini disebabkan karena investor bereaksi dengan adanya informasi yang diperoleh mengenai peristiwa Pemilihan Umum Gubernur DKI Jakarta Tahun 2017. Dengan adanya reaksi dari investor maka terdapat perbedaan abnormal return sebelum dan sesudah peristiwa Pemilihan Umum Gubernur DKI Jakarta Tahun 2017. Hal yang sama diungkapkan oleh Filsaraei (2013) ; Azizah (2017) yang menyatakan bahwa informasi yang diterima oleh investor akan memberikan sinyal bagi investor dalam pengambilan keputusan investasi. Investor akan bereaksi pada waktu pengumuman tersebut diterima atau pada waktu terjadinya suatu peristiwa, sehingga terdapat perbedaan abnormal return sebelum peristiwa dan sesudah isu politik (reshuffle kabinet Jilid II). Dengan adanya abnormal return yang diperoleh dapat dikatakan bahwa reshuffle kabinet Jilid II memiliki kandungan informasi bagi pelaku pasar modal.

Hasil penelitian ini sesuai dengan penelitian yang dilakukan oleh Permana (2013) yang menyatakan bahwa terdapat perbedaan abnormal return positif signifikan pada sektor keuangan sebelum dan sesudah peristiwa Pilkada Gubernur 
DKI Jakarta 20 September 2012. Hasil penelitian ini juga didukung oleh penelitian yang dilakukan oleh Wibowo (2017) yang menyatakan terdapat perbedaan positif signifikan rata-rata abnormal return saat sebelum dan setelah peristiwa pengumuman Paket Kebijakan Ekonomi Tahap I Jokowi - JK. Serta selaras dengan penelitian yang dilakukan oleh Azizah (2017) yang menyatakan terdapat perbedaan yang signifikan antara abnormal return sebelum peristiwa dan sesudah isu politik (reshuffle kabinet Jilid II).

Implikasi dalam penelitian ini menunjukkan bahwa terdapat abnormal return disekitar peristiwa Pemilihan Umum Gubernur DKI Jakarta Tahun 2017 dan terdapat perbedaan abnormal return sebelum dan sesudah peristiwa Pemilihan Umum Gubernur DKI Jakarta Tahun 2017. Hasil dari penelitian ini dapat dijadikan bukti empiris bahwa suatu peristiwa politik dapat mempengaruhi pasar modal. Hasil penelitian ini juga dapat dijadikan referensi dan acuan di dalam melakukan investasi di pasar modal. Penelitian ini dapat membuktikan teori pasar efisien bentuk setengah kuat dimana tedapat adanya abnormal return. Abnormal return ini diperoleh karena terdapat informasi yang relevan mengenai suatu peristiwa politik yang terjadi dan dapat dijadikan acuan dalam pengambilan keputusan berinvestasi. Penelitian ini memberikan kontribusi positif bagi investor yang akan melakukan investasi di pasar modal. Investor sebaiknya mencari informasi yang baik dan relevan sebagai pedoman berinvestasi untuk meminimalisir resiko saat terjadinya suatu peristiwa politik. 


\section{SIMPULAN DAN SARAN}

Simpulan yang diperoleh yaitu terdapat abnormal return disekitar peristiwa Pemilihan Umum Gubernur DKI Jakarta Tahun 2017. Terdapat abnormal return disekitar peristiwa Pemilihan Umum Gubernur DKI Jakarta Tahun 2017 menandakan bahwa peristiwa politik tersebut mengandung informasi yang relevan bagi investor untuk pengambilan keputusan investasi. Selain itu, kondisi politik yang stabil menjadi pertimbangan investor untuk masuk ke pasar modal sehingga terdapat abnormal return disekitar peristiwa Pemilihan Umum Gubernur DKI Jakarta Tahun 2017. Terdapat perbedaan abnormal return sebelum dan sesudah peristiwa Pemilihan Umum Gubernur DKI Jakarta Tahun 2017. Hal ini disebabkan karena karena investor bereaksi dengan informasi yang diperoleh mengenai peristiwa politik Pemilihan Umum Gubernur DKI Jakarta Tahun 2017. Dengan adanya reaksi dari investor maka terdapat perbedaan abnormal retrun sebelum dan sesudah peristiwa Pemilihan Umum Gubernur DKI Jakarta Tahun 2017. Sehingga dapat dikatakan bahwa peristiwa Pemilihan Umum Gubernur DKI Jakarta Tahun 2017 memiliki kandungan informasi.

Saran yang dapat diberikan adalah bagi calon investor agar dapat menjadi suatu pertimbangan sebelum melakukan investasi di pasar modal saat suatu peristiwa politik terjadi. Bagi peneliti selanjutnya dapat meneliti kembali dengan menggunakan variabel volume perdagangan untuk dapat mengukur reaksi pasar modal pada saat terjadinya suatu peristiwa politik. 


\section{REFERENSI}

Azizah, M. N. (2017). Pengaruh Isu Politik terhadap Reaksi Pasar Modal Indonesia. Jurnal Ilmu Dan Riset Akuntansi, 6(5), 1742-1756.

Bursa Efek Indonesia. 2017. Pengumuman Saham yang Masuk dan Keluar dalam Perhitungan Indeks Kompas 100 No. Peng-00024/BEI.OPP/01-2017. Tersedia pada http://www.idx.co.id diunduh pada tanggal 1 Juli 2017.

Cahyono, Hadi \& Fitradiansyah, Hafiz. Abnormal Return Differences Before And After Amnesty Tax Policy 2016 -2017Period II And III (Event Study at Company divided in LQ45 Index). International Journal of Entrepreneurship and Business development. 1(1), 39-74.

Chandra, C. H., Anastasia, N., Memarista, G., Ekonomi, F., Petra, U. K., \& Siwalankerto, J. (2014). Perbedaan Average Abnormal Return , Average Trading Volume Activity Sebelum dan Sesudah Pemilu di Indonesia. FINESTA, 2(1), 114-118.

Diniar, A. H., \& Kiryanto. (2015). Analisis Dampak Pemilu Presiden Jokowi terhadap Return Saham (Studi Kasus Saham LQ-45 di Bursa Efek Indonesia). Jurnal Akuntansi Indonesia, 4(2), 97-108.

Fahmi, Irham. (2012). Teori Portofolio dan Analisis Investasi. Bandung: Alfabeta.

Fama, E. F. (1969). American Finance Association Efficient Capital Markets : A Review of Theory and Empirical Work. The Journal of Finance, 25(2), $28-30$.

Filsaraei, Mahdi. An Empirical Analysis for Abnormal Returns from Initial Public Offerings (IPOs): evidence of Iranian oil and chemical industries. International Journal of Accounting and Financial Reporting. 3(1), 143161.

Ghozali, I. (2013). Aplikasi Analisis Multivariate dengan Program IMB SPSS 21 Update PLS Regresi. Semarang: Badan Penerbit Universitas Diponegoro.

Hartawan, M. W. (2015). Analisis Perubahan Volume Perdagangan Saham Dan Abnormal Return Sebelum Dan Sesudah Pemilu Legislatif 9 April 2014 ( Event Study Pada Sektor-Sektor Industri Di Bursa Efek Indonesia ). EJournal, 3(1).

Hartono, J. (2015). Teori Portofolio dan Analisis Investasi (Edisi Kese). Yogyakarta: BPFE.

Ikatan Akuntan Indonesia. 2011. Standar Akuntansi Keuangan. Jakarta: Salemba 
Empat.

Imelda, Siregar, H., \& Anggraeni, L. (2014). Abnormal Returns and Trading Volume in the Indonesian Stock Market in Relation to the Presidential Elections in 2004, 2009, and 2014. International Journal of Administrative Science \& Organization, 21(2), 66-76.

Jayanti, Y. D. (2015). Reaksi Pasar Modal Indonesia terhadap Peristiwa Pemilu Presiden 2014 (Event Study pada Saham yang Terdaftar dalam Kelompok Indeks LQ - 45). Jurnal Sekolah Tinggi Ilmu MADANI Balikpapan.

Julio, B., \& Yook, Y. (2012). Political Uncertainty and Corporate Investment Cycles. Journal of Finance, 67(1), 45-84.

Laksmi, N. K. U., \& Ratnadi, N. M. D. (2015). Perbedaan Abnormal Return Sebelum dan Sesudah Pengumuman Penurunan Harga BBM. Terdapat selisih positif diperlukan dan mempengaruh. E-Jurnal Akuntansi Universitas Udayana, 13, 1029-1056.

Market Bisnis. 2017. Historical Price. Tersedia pada www.markert.bisnis.com. diunduh pada tanggal 1 Juli 2017.

Mentari, N. M. I. (2016). Reaksi Pasar Terhadap Peristiwa Pengumuman Cash Dividend Pada Industri Manufaktur Yang Terdaftar Di Bei. E-Jurnal Manajemen Unud, 5(2), 1043-1073.

Nabila, F., \& Khairunnisa. (2015). Analysis of The Differences In Abnormal Return Before and After Political Event (Presidential Election) In Indonesia And Singapore (Event Study On Companies Listed On Lq45 At Idx And Strait Times Index At SGX). E-Proceeding of Management, 2(2), 1640-1648.

Nezerwe, Y. (2013). Presidential Elections and Stock Returns in Egypt. Review of Business and Finance Studies, 4(2), 63-68.

Permana, H. T. (2013). Perbedaan Abnormal Return pada Sektor Keuangan Sebelum dan Sesudah Peristiwa Pilkada Gubernur DKI Jakarta 20 September 2012. Jurnal Ilmiah Mahasiswa Universitas Surabaya, 2(1), 19.

Peterson, P. (1989). Events Studies: A Review of Issues and Methodology. Quarterly Journal of Business and Economics, 28(3), 36-66.

Pratama, I. G. B. (2015). Reaksi Pasar Modal Indonesia terhadap Peristiwa Politik (Event Study pada Peristiwa Pelantikan Joko Widodo Sebagai Presiden Republik Indonesia ke-7). S1 AK Universitas Pendidikan Ganesha, 3(13), 
$1-11$.

Purba, F. (2017). Analisis Perbedaan Reaksi Pasar Modal Indonesia Sebelum Dan Sesudah Peristiwa Non Ekonomi. Jurnal Administrasi Bisnis (JAB), 51(1), $115-123$.

Purnama, Yoga Satya dan Khairunnisa. (2015). Capital Market Reaction on the Announcement of the Result of Presidential Election in 2009 and 2014 at Indonesian. E-Proceeding of Management, 2(1), 246-254.

Puteri, Lintang Prathama \& Musadieq, M. Analysis of Differences on Abnormal Return and Trading Volume Activity (TVA) Because of Inncreasing Cigarette Price (Study at stocks listed in LQ-45 index on August 2016January 2017). Jurnal Administrasi Bisnis (JAB). 50 (4), 139-145.

Putri, S. R. (2016). Analysis Study of The Difference of Abnormal Return and Trading Volume Activity Before and After Announcement of An Economic Policy Package Volume II (A Case Study on A Share Group LQ45 Stocks on the Indonesia Stock Exchange (BEI) year 2015). EProceeding of Management, 3(3), 2808-2815.

Respati, N. W. (2014). Reaksi Pasar Modal terhadap Pengumuman Sengketa Hasil Pemilihan Presiden 2014. JSAI, 1(1), 12-20.

Savita, \& Ramesh, A. (2015). Return Volatility Around National Elections: Evidence from India. Procedia - Social and Behavioral Sciences, 189, 163-168. https://doi.org/10.1016/j.sbspro.2015.03.210

Sirait, R. S. (2012). Dampak Pergantian Menteri Keuangan RI Tahun 2010 terhadap Abnormal Return Perusahaan Perbankan yang Terdaftar di BEI. E-Jurnal BINAR AKUNTANSI, 1(1), 14-22.

Suryanto. Analysis of Abnormal Return Before and After The Announcement of Investment Grade Indonesia. International Journal of Business and Management Review, 3(1), 11-23.

Tandelilin, E. (2010). Portofolio dan Investasi (Edisi Pert). Yogyakarta: Kanisius.

Utami, Dianingsih Putri dan Asandimitra, Nadia. Analysis of Abnormal Return, Trading Volume, And Bid-Ask Spread At the Period of Stock Split Announcement. 8(4), 83-93.

Wardhani, L. S., \& Djazuli, A. (2012). Reaksi Pasar Modal Indonesia terhadap Peristiwa Pemilihan Gubernur DKI Jakarta Putaran II 2012. Jurnal Ilmiah Mahasiswa Fakultas Ekonomi Dan Bisnis Universitas Brawijaya, 1(1). 
Wibowo, A. (2017). Reaksi Investor Pasar Modal Indonesia terhadap Paket Kebijakan Ekonomi Tahap I Jokowi-JK. Media Ekonomi Dan Manajemen, $32(1), 58-70$.

Yuniarthi, N. N. S. (2016). Reaksi Pasar Modal terhadap Pencalonan Jokowi Menjadi Presiden Republik Indonesia. E-Jurnal Akuntansi Universitas Udayana, 16, 951-977.

Zulfikar, Rizka \& Mayvita, P. A. The Effects of Political Events Against Abnormal Return and Total Volume Sharia Shares Activity That Listed in Jakarta Islamic Index (JII). Jurnal Ilmiah Bidang Akuntansi dan Manajemen (JEMA). 14(2), 157-168. 